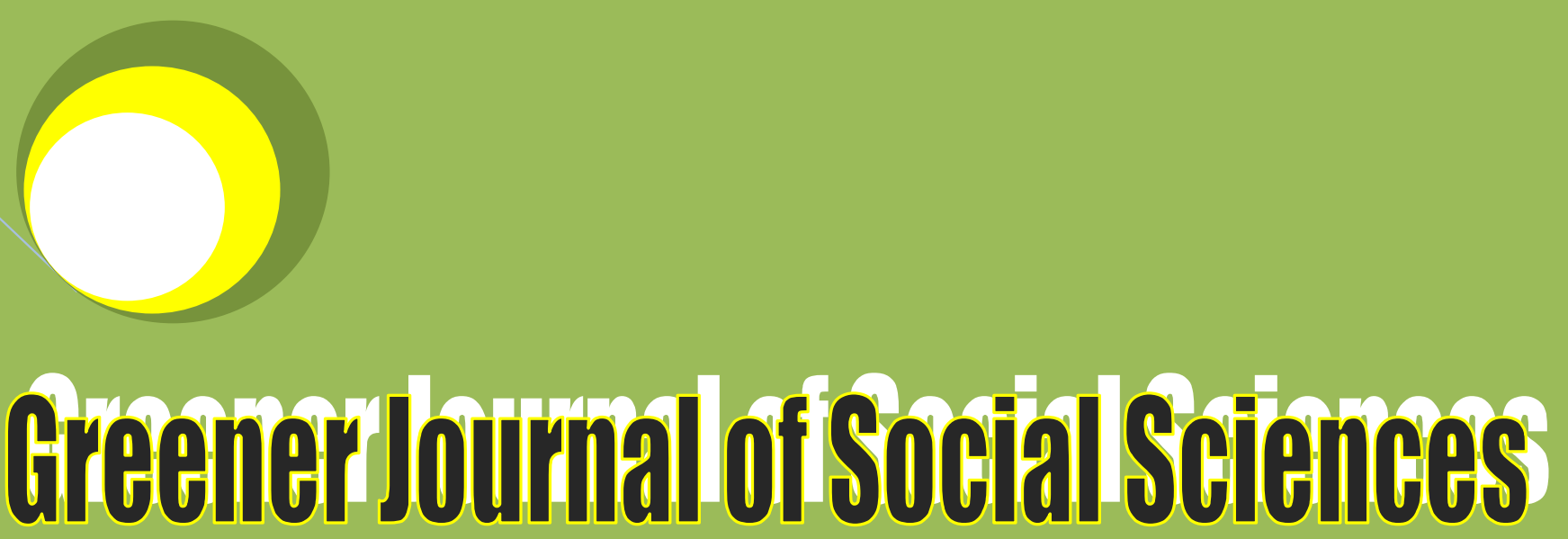

ISSN: 2276-7800 ICV: 5.99

Submitted: $10 / 10 / 2017$

Accepted: 18/10/2017

Published: 30/10/2017

DOI: http://doi.org/10.15580/GJSS.2017.4.101017146

Small Wars and the

War Crime Dilemma:

The "Weaponization"

of the Laws of War in

Non-Conventional

Warfare

By

Emah Saviour Peter

Ekah James Akpan, Ph.D 


\title{
Small Wars and the War Crime Dilemma: The "Weaponization" of the Laws of War in Non-Conventional Warfare
}

\section{Emah Saviour-Peter and Ekah James Akpan, Ph.D}

\author{
Department of History and International Studies, University of Uyo, Nigeria. \\ *Corresponding Author’s E-mail: saviouremah@ gmail. com; Phone: +234-810-2911-705, +234-806-1622-626 \\ When 'savage or semi-savage peoples effect ruses, surprises, or massacres' against 'regular' troops, the \\ uncivilized enemy must not be allowed to benefit from the international law of armed conflict.
}

Elbridge Colby, 1927

\begin{abstract}
The laws of armed conflict (LOAC), in an inadvertent but macabre paradox, are serving as weapons of war for rebels in asymmetric warfare, particularly in insurgencies. Thus, this paper is an inquiry into how guerrillas have capitalized on the International Humanitarian Laws, which tend to limit states behaviour and actions in armed conflicts. Asymmetrical conflicts are often fought between a state abiding by the laws of war or International Humanitarian Law, and rebel groups that more or less never obey these regulations and have very little need or sanction to do so. The Geneva and Hague Conventions and their protocols, which outlined the laws of war, were formulated in an era of conventional combat, when wars were fought between state actors and by armies that observed the rules of armed conflict. However, the nature of warfare has greatly altered in recent decades with the increased participation of civilians and the use of guerilla tactics, which makes the enemy virtually anonymous. The battle line is now drawn in urban and choked up areas, while army uniforms have almost become obsolete. These developments have raised arguments as to the efficacy of the present International Humanitarian Law to regulate non-conventional warfare. The present paper adds to the discourse by asserting that the revolution in warfare does not only present a dilemma to national armies in non-conventional warfare, but also gives the insurgents an opportunity to "weaponize" the laws of war for their own leverage, hence, the need to revolutionize the laws of war in tandem with the revolution in warfare itself.
\end{abstract}

Keywords: Laws of Armed Conflict, Asymmetric Warfare, Insurgencies, Dilemma, Weaponization.

\section{INTRODUCTION}

The conflict between Israel and Hamas provides a typical example of asymmetric warfare. The duo fought a ferocious three-week battle in the Gaza Strip in December 2008 that ended inconclusively in January the following year with the Israeli declaration of a unilateral cease-fire. Three months later, the conflict theatre repaired from the Gaza Strip to Geneva with the appointment of South African judge Richard Goldstone, by the UN Human Rights Council, to lead a fact-finding mission to Gaza. Another four months later, Goldstone's mission reported that, contrary to international law, both Hamas and Israel had committed war crimes and crimes against humanity. ${ }^{1}$ The report was endorsed at the UN with 114:18 votes. ${ }^{2}$ However, it was startling to observe that the United States, which is possibly the world's most vociferous advocate of human rights, completed the $18^{\text {th }}$ vote against the Goldstone report. Deputy US ambassador to the UN, Alejandro Wolff, attempted to dilute this scare by explaining, "We believe that the Goldstone report is deeply flawed, including its failure to deal adequately with the asymmetrical nature of the Gaza conflict." ${ }^{3}$ In Nigeria, the federal government has been engaging Boko Haram insurgents in the northeastern part of the country in a protracted combat since 2009. However, the same United States, until recently, refused to donate or even sell arms to Nigerian government over allegations of

'Yves Winter, "The Asymmetric War Discourse and its Moral Economies: A Critique," International Theory, Cambridge University Press, 2011, 3:3, p.488.

2 lbid

3 'Explanation of Vote by Ambassador Alejandro D. Wolff, Deputy Permanent Representative, on a UN General Assembly Resolution on the UN Fact-Finding Mission on the Gaza

Conflict, in the General Assembly', US Mission to the United Nations, New York, 5 November 2009. Accessed 16 April 2016 , http://usun.state.gov/briefing/statements/2009/131448.htm 
human rights violation and war crimes by the government forces. A 2015 report by Amnesty International, just like the Goldstone report, also implicated the Nigerian government for violation of laws of war. ${ }^{4}$ Such ambivalent American stance (in Israel-Hamas and Nigeria-Boko Haram) is the nature of the controversy as to what constitutes war crimes in such asymmetrical conflicts and whether or not the current international humanitarian law can adequately streamline the laws of war in irregular warfare.

The debate has impelled two main questions: how can the international humanitarian law forbidding attacks on civilians be applied in an irregular warfare where the distinction between a civilian and the enemy is so haze, when the only possible opportunity for the government's victory involves attacking the enemy's source of protection which in this case are often the civilians. The second question is how can the guerilla enemy be made to obey international humanitarian laws when they are not susceptible to international sanctions, the most effective, and perhaps, only way of compelling obedience to international law, when they do not have a territory that a UN coalition can invade and occupy to compel obedience, as was done in Iraq during the Gulf War. Viewed from this perspective, this paper suggests that the existing laws of war is serving as weapons of war for insurgents in asymmetric warfare. Hence, the need to review the existing laws in accordance with the revolution in warfare.

\section{International Humanitarian Law and the Laws of Armed Conflicts}

International law refers to the principles, rules, and standards that govern the relations of nation states and nonstate actors in international system. International law comprises different branches, including international laws relating to the environment, the sea, human rights, sovereignty, commerce, and even the outer space. There are at least three phrases commonly used to describe the branch of international law relating to the means and methods of conducting warfare. In its simplest form, they are called the Laws of War (LoW), while others call them the Laws of Armed Conflict (LOAC), which is probably more accurate because not all armed conflicts are qualified to be designated as wars. The International Committee of the Red Cross (ICRC) gave the third label for these laws, International Humanitarian Laws (IHL), which may be much accurate because not all of the rules are expressly connected to the conduct of warfare, but some are meant to serve other humanitarian values, especially by regulating the treatment of civilians during wars. ${ }^{5}$

International humanitarian laws, laws of war or laws of armed conflicts are intended to determine the justifications for, and regulate ways and means of, conducting warfare between states in the international system, sometimes within the territorial boundaries of nation states. The history of warfare itself is as old as the history of humankind, if not older. However, the regulation of warfare only evolved with the recognition by nations of the great human toll, collateral damage and long-term effects of the barbaric and unregulated conduct of hostilities. Prior to its codification as part of international law, the laws of war were recognized and observed by dyads in war for a long time. The ancient Greeks for instance observed the laws of war and sanctioned war crimes in their series of war. They proscribed summary execution of Prisoners of War (POW), attack on non-combatants, the pursuit of defeated opponents beyond a limited time and space and many other war crimes that the current international humanitarian laws still prohibit. 6

However, the laws of armed conflict as obtainable today developed from several multilateral conferences where the representatives of many nation states agreed on what they considered the right and binding ways of conducting warfare. Of these conferences, the gamut of international humanitarian law developed in two spheres: Geneva Convention and Hague Convention, and their additional protocols. The former laid regulations for the protection of people that are affected by armed conflict, while the latter laid regulations for the means and methods of conducting warfare, such as the use of certain weapons and the treatment of PoWs. ${ }^{7}$ Swiss philanthropist, Jean Henri Dunant, was the first to document the necessity for such laws in his book, Un Souvenir de Solferino (A Memory of Solferino, 1862) where he described the suffering of wounded soldiers at the northern Italian battlefield of Solferino in June 1859. Dunant also campaigned for the establishment of a relief society and the adoption of a treaty that would give protection on the battlefield to the wounded and those who assisted them. These proposals eventually resulted in the founding of the International Committee of the Red Cross (ICRC). ${ }^{8}$

Deriving its name from Geneva, the Switzerland city where the conventions were discussed and enacted, the Geneva Conventions were a series of international agreements that created and developed international humanitarian law to protect wounded combatants, prisoners of war, and civilians during times of armed and nonarmed conflicts. The first Geneva Convention (GC 1) was adopted in 1864. Since then, GC I was revised three

\footnotetext{
${ }^{4}$ Amnesty International, Stars on their Shoulders, Blood on their Hands: War Crimes Committed by the Nigerian Military, London: Amnesty International Ltd, June, 2015.

${ }^{5}$ For detailed descriptions of IHL, see Yoram Dinstein, The Conduct of Hostilities Under the Law of International Armed Conflict, Cambridge University Press, 2004; Jean-Marie Henkaerts and Louise Doswald-Beck, Customary International Humanitarian Law (ICRC, Cambridge University Press, 2005

${ }^{6}$ see Ibid

${ }^{7}$ Frida Lindström, "Asymmetric Warfare and Challenges for International Humanitarian Law:

Civilian Direct Participation in Hostilities and State Response", Master's Thesis in Public International Law, submitted to the Department of Law, Uppsala University, 2012, p.15

${ }^{8} \mathrm{Kolb}$ and Hyde, An Introduction to the International Law of Armed Conflicts, Oxford: Hart Publishers, 2008, pp. 37-38. www.gjournals.org 
times in 1906 (GC 2), 1929 (GC 3), and 1949 (GC 4) respectively, with new scope and coverage added to each amendment. Some of the war crimes established at the four Geneva Conventions include: willful killing, torture or inhuman treatment, including biological experiments; willfully causing great suffering or serious injury to body or health; compelling one to serve in the forces of a hostile power; and willfully depriving one of the right to a fair trial, taking of hostages; extensive destruction and appropriation of property not justified by military necessity and carried out unlawfully and wantonly; and unlawful deportation, transfer, or confinement. ${ }^{9}$ As an accompaniment to the Geneva Conventions, two additional protocols were added in 1977. The first protocol provides protection to victims of armed conflicts in cases where people are fighting in the exercise of their right of self-determination, while the second provides protection to victims of non-international armed conflicts.

The Hague Conventions (HC) of 1899 and 1907 on the other hand governs the conduct of international armed and non-international armed conflicts on land, at sea, and in air. The cardinal principles of the Hague Conventions pertaining to International Humanitarian Laws are that:

(a) Parties to a conflict do not have an unlimited choice of means and methods in armed conflicts;

(b) The causing of superfluous and unnecessary suffering is prohibited; and

(c) The only legitimate object of war is to overpower or weaken enemy forces in order to be in control of territory or to enforce a political will, not to kill as many as possible. ${ }^{10}$

Apart from the Geneva and Hague Conventions, rules governing ways, means and methods of warfare can also be found in numerous other conventions and treaties, each of which regulate specific areas of the conduct of war. Examples of these are the prohibition on the use of poisonous gases, the prohibition on the use of biological weapons, the prohibition on the use of environmental modification techniques for military or hostile purposes, the prohibition on the use of chemical weapons, the prohibition on the use of anti-personnel mines, the prohibition on the use of camouflage on neutral grounds, and the certain conventional weapon convention with its protocols.

From the above historical background, it is noticeable that international humanitarian laws or the laws of war have developed beyond the mere protection of soldiers in the battle field and the regulation of their conducts in warfare to also encompass the protection of civilians and others affected by the war and the regulation of the civil-military relations during war times. This broader civilian inclusion became necessary with the increasing civilian role and participation, directly or indirectly, in warfare. In this direction, the World War II was a turning point, where warfare moved from being limited to total, involving virtually the entire civilian population as well as the soldiers.

\section{Understanding Asymmetric and Non-Conventional Warfare}

The nature of warfare has altered significantly over the last few decades, owing to technological advances and the emergence of non-state actors like Private Military Contractors, Military Industrial Complexes and Terrorist Organizations as prominent and rogue actors in contemporary warfare. In this context, asymmetric warfare means war between two unequal parties in which one party in the conflict (often the lesser party) adopts "different" legally and morally controversial means, strategies, and tactics to maximize an advantage, take the initiative, or exploit the opponent's weaknesses in armed conflict. This kind of conflict has been addressed by many nomenclatures: 'low-intensity conflicts' (Kitson 1971), 'fourth-generation warfare (4GW)' (Lind et al. 1989; Lind 2004), 'small wars' (U.S. Marine Corps 1940; Merom 2003), 'network centric warfare' (Cebrowski and Garstka 1998; see also Arquilla 2007), 'authorless war' (Appadurai (2006, 16-17), 'nonconventional', 'hybrid' (Mattis and Hoffman 2005), and 'asymmetric' wars (Mack 1975; Paul 1994; Arregui'n-Toft 2001), among other designations. Although each of these terms has a technical peculiarity, they all almost mean the same thing. In a sense, all warfare could be labeled as asymmetric since no two adversaries - in conventional and nonconventional warfare - have ever been equal in size and power. However, asymmetric warfare between a sovereign state and a non- state actor manifest in two kinds, terrorism and insurgency. The later shall constitute the focus of our discussion.

States face primarily two dimensions of security challenges, external-interstate- security challenge, and internal- intrastate- security challenge. The latter has been the most prevalent in the post cold war era, with most of them taking the form of insurgencies. Insurgents wage revolutionary warfare and, for the most part, insurgencies are revolutions. ${ }^{11}$ It involves an irregular kind of warfare that applies unconventional techniques, asymmetrical armies, low intensity operations and guerrilla tactics against a state. Insurgents use a mixture of subversion, sabotage, political, economic, psychological, and armed actions to achieve their political aims of overthrowing a perceived illegitimate government. The United States joint publication on counterinsurgency

\footnotetext{
${ }^{9}$ see GCl- Geneva Convention for the Amelioration of the Condition of the Wounded and Sick in Armed Forces in the Field, of 12 August 1949; GCII-Geneva Convention for the Amelioration of the Condition of Wounded, Sick and Shipwrecked Members of Armed Forces at Sea, of 12 August 1949; GCIII- Geneva Convention relative to the Treatment of Prisoners of War, of 12 August 1949; GCIV Geneva Convention relative to the Protection of Civilian Persons in Time of War, of 12 August 1949

${ }^{10} \mathrm{Kolb} \&$ Hyde, An Introduction to the International Law of Armed Conflicts, Oxford: Hart Publishers, 2008, p. 167

${ }_{11}$ "Strategy and Tactics of Guerrilla Warfare," https://en.wikipedia.org/wiki/ Strategy_and_t actics_of_guerrilla_warfare.
} 
defines insurgency as the organized use of subversion and violence to seize, nullify, or challenge political control of a region. ${ }^{12}$ The primary goal of insurgents therefore is to gain political control of a population and a geographic area, including its resources. Hence, Political power, not military power is the central issue in insurgencies (though a decree of military power is pertinent), and insurgencies are designed to weaken government control and legitimacy while increasing insurgent control and influence, especially with the relevant populations.

Brein O'Neill identifies insurgency as probably, "the most prevalent type of armed conflict since the creation of organized political communities". ${ }^{13}$ O'Neill thus defines insurgency as: "a general overarching concept that refers to a conflict between a government and an out group or opponent in which the latter uses both political resources and violence to change, reformulate, or uphold the legitimacy of one or more of four key aspects of politics". ${ }^{14}$ The four aspects of politics here include, the integrity of the borders and composition of the nation state, the political system, the authorities in power, and the policies that determine who gets what in societies. However, erstwhile US President Kennedy provided a more apt description of insurgency thus:

...This is another type of war, new in its intensity, ancient in its origin-war by guerrillas, subversives, insurgents, assassins, war by ambush instead of by combat; by infiltration, instead of aggression, seeking victory by eroding and exhausting the enemy instead of engaging him. It is a form of warfare uniquely adapted to what has been strangely called 'wars of liberation,' to undermine the efforts of new and poor countries to maintain the freedom that they have finally achieved. It preys on economic unrest and ethnic conflicts. It requires in those situations where we must counter it, and these are the kinds of challenges that will be before us in the next decade if freedom is to be saved, a whole new kind of strategy, a wholly different kind of force, and therefore a new and wholly different kind of military training. ${ }^{15}$

When taken together, the unique nature of insurgency indicates that such struggles are essentially dissimilar from conventional warfare. The first trait of thriving insurgencies is that they are usually protracted struggles. Insurgencies are measured in decades, not months or years. ${ }^{16}$ The Chinese Communists fought for 27 years. The Vietnamese fought the U.S. for 30 years. The Palestinians have been resisting Israel since at least 1968, The Malaya Emergency and the El Salvadoran insurgency each lasted 12 years. Time, thus becomes a twoedged sword in the hands of an insurgent (for maximizing their preparations and for eroding the government legitimacy), and both edges cut into the chances for the government to win. Hence, the argument that insurgents win when they do not lose. The primary source of an insurgent's strength is its underground organization or center of gravity, that is, the hostile political infrastructure within the target population. Accurate and timely intelligence is also vital to insurgent success as well as well-placed agents within the government and its military circles that provide information on the government's counterinsurgency plans. Insurgent sympathizers within the local population as well provide the insurgent forces with important supplies that are readily available within the society under attack. ${ }^{17}$ They can obtain simple medical supplies and clothing in small amounts without suspicion because it is always difficult to distinguish an insurgent from an ordinary civilian. In fact, scholars have devoted a lot of time and space to emphasize the role that civilian support plays in the success of insurgencies; some have gone as far as qualifying civilian support as the most efficacious bludgeon in this respect.

These complex mixtures of dimensions, motives and strategies in insurgency warfare make it a battle for the hearts and minds of the population. In other words, unlike conventional warfare, it is not the party that wields a more sophisticated technology and the largest number of military personnel that often wins in insurgent warfare but the party that wins the support and sympathy of the population, though military might and personnel are also quite important. A successful insurgency warfare strategy is dependent on sanctuary and the support of the population. Being able to withdraw to a safe haven quickly is crucial for the guerilla fighter, since he will not be able to defeat his militarily superior opponent (the national army) on an open battlefield. Having the support of the population is also necessary since guerilla fighters are dependent on the locals for the provision of and supplies of food, intelligence, shelter, and in some cases, arms. This reliance on the civilian population means that civilians often will be drawn into the conflict in one way or another, which in turn have decisive implications on the conflict cadence.

\footnotetext{
${ }^{12}$ U.S. Government Counterinsurgency Guide, Bureau of Political-Military Affairs, Department of State. 2009. Retrieved May 1, 2016. ${ }^{13}$ O'Neill, B., Insurgency and Terrorism: From Revolution to Apocalypse (2nd ed.). Washington D. C.: Potomac Books, Inc. 2005, p.1 ${ }^{14} \mathrm{O}$ Niell, 2002 cited in Taber, R., War of the Flea: The Classic Study of Guerilla Warfare, Washington D. C.: Potomac Books, Inc., p.viii ${ }^{15}$ Excerpts from President Kennedy's Address at Graduation Exercises of the U.S. Military Academy, June 6, 1962. Source: The Pentagon Papers, Gravel Edition, Volume 2, p. 813

${ }^{16}$ Thomas Hammes, Countering Evolved Insurgents Network, http://www.au.af. mil/au/ awc /awcgate/milreview/hammes.pdf, Retrieved 24 ${ }^{\text {th }}$ May, 2016

${ }^{17}$ see U.S. Government Counterinsurgency Guide (PDF). Bureau of Political-Military Affairs, Department of State. 2009. Retrieved May 1, 2016.
} 
In sum, asymmetric warfare such as insurgency and terrorism involve combat between a states military establishment and a non-state (often rogue and surreptitious) organization. The later seeks to avoid an open battle on a conventional battlefield, because the state will have both a qualitative and quantitative military advantage. Although several countries are beginning to introduce counterinsurgency trainings into their military training curriculum, most conventional armies, especially those of third world countries (where insurgencies frequently arise), are trained to operate in large units, against enemies that are assembled in one geographical theater, and that fight with almost the same type of weaponry. This is a sharp contrast to their non-state rogue opponents who are trained to operate in small units, against non combatant targets in choked up settings, and to disperse quickly afterwards as well as blur the lines between combatants and civilians.

\section{The Laws of War as Weapons for Insurgents}

The Encarta dictionary defines weapon in two ways: as a device designed to inflict injury or death on an opponent and as something used as a way of getting an advantage in a situation. The second definition shall be our working definition here. There are two basic categories of weapons in military history- offensive and defensive. Offensive weapons are used to attack the enemy, for example, mortars, mines and drones; while defensive weapons are used as shield against enemy attack, such as plates, bracelets and anti ballistic missiles. However, some weapons like tanks tend to play both roles. In asymmetric conflicts like insurgencies, the insurgents use the laws of armed conflicts as an advantage to launch an attack on the state as well as a shield against reprisal attacks from the military.

The canon of international humanitarian law often exploited by dissident militias to gain offensive and defensive advantage over organized militaries is the rules on the treatment of non-combatants during armed conflicts. Art. 85 (3a), Art.51 (2), Art. 52 (1), Art. 85 (3b) and 85 (3d) of the Protocol Additional to the Geneva Conventions of 12 August 1949, and relating to the Protection of Victims of International Armed Conflicts (Protocol I), of 8 June 1977; Rule 14, 35, 36, 37 of ICRC Study on Customary International Humanitarian Law, (ed. 2005), Art. 25 of Regulations Respecting the Laws and Customs of War on Land annexed to The Hague Convention of 18 October 1907 Respecting the Laws and Customs of War on Land (Convention No. IV), among others all frown at any direct or indirect attack on the civilian population during armed conflicts. Insurgents do not obey these rules and have no necessity to do so. Article $51(5 \mathrm{~b})$ of API prohibits any attack that "may be expected to cause incidental loss of civilian life, injury to civilians, damage to civilian objects, or a combination thereof, which would be excessive in relation to the concrete and direct military advantage anticipated." 18 The complementary precautionary principle, articulated in article 57(2) of API, requires that states take "all feasible precautions" in the choice of means and methods of attack with a view to avoiding, or at least minimizing, incidental civilian loss or damage. Moreover, it requires that an attack be suspended if it becomes apparent that it may cause incidental civilian loss and that effective advance warning be given of attacks which may affect the civilian population, "unless circumstances do not permit." Article 48 of AP1 states that parties in conflict shall "at all times distinguish between the civilian population and combatants and between civilian objects and military objectives" and shall direct their operations only against the latter. In addition, article 51(4) expressly prohibits indiscriminate attacks that are not, or cannot be, directed at a specific military objective.

As stated earlier, unlike professional soldiers who go to the battle on their army uniforms as stipulated by international law, insurgent have a strong spur to blur the lines between combatants and non-combatants. Like every other civilian, they do not wear any distinctive army uniform, it is often the same uniform as the state army's (if at all), and they embed themselves in schools among pupils and students, in hospitals among patients and doctors, in churches/mosques among worshippers and preachers, in flights among civilian passengers. Insurgents conceal explosives and other weapons in civilian residences. More strikingly, they often place civilians in harm's way, at times with the consent of the civilians. As rightly summarized by Michael Gross:

[Many civilians] aid and abet insurgents by storing their weapons, producing their propaganda, providing them with food and shelter, and even agreeing to act as civilian shields. ${ }^{19}$

Such was the tactics adopted by Hamas and Hizbullah, the Sri Lankan experience with the Tamil Tigers, Israeli experience in Lebanon (2006) and Gaza (2008-9), the Russian experience in Chechnya, the Nigerian experience with Boko Haram and the Georgian experience in South Ossetia.

The logic is that if a strike by the counter insurgent forces hits any civilian, it will provoke international indignation against the state for violation of international law. This way, the government forces may either loose the co-operation of neighboring countries concerning the elimination of insurgents' sanctuaries or, as was the

\footnotetext{
${ }^{18}$ Protocol Additional to the Geneva Conventions of 12 August 1949, and Relating to the Protection of Victims of International Armed Conflicts (Protocol I), 8 June 1977.

${ }_{19}$ Michael Gross, Moral Dilemmas of Modern War: Torture, Assassination, and Blackmail in an Age of Asymmetric Conflict. Cited in Carpenter, Charli. "Fighting the Laws of War: Protecting Civilians in Asymmetric Conflict." Foreign Affairs Mar.-Apr. 2011: 146.
} 
case with Nigeria, not receive any external supplies of arms and logistics for fear of human rights violation. Thus, the insurgents would have exploited the laws of war as an advantage to attack the legitimacy of the government they seek to overthrow. Such situations often put the state forces in a dilemma: to attack the civilians shield or not to attack. The United States experience in Somali provides a typical case in point of the dilemma here. In October 1993, a United States counterinsurgency force was caught up in gunfire in the streets of Mogadishu, which resulted in the death of about 18 American soldiers. In rage, American soldiers are said to have killed over one thousand women and children who were being used as shields by the militia. Similarly, in the course of Nigerian counter-insurgency campaign, Amnesty international reports that:

\begin{abstract}
Military forces have extra-judicially executed more than 1,000 people; they have arbitrarily arrested at least 20,000 people, mostly young men and boys; and have committed countless acts of torture. Hundreds, if not thousands, of Nigerians have become victims of enforced disappearance; and at least 7,000 people have died in military detention as a result of starvation, extreme overcrowding and denial of medical assistance. ${ }^{20}$
\end{abstract}

However, the Nigerian military on certain occasions have either denied such figures, or justify them on the grounds that the civilians involved were directly or indirectly abetting insurgents, or that they were mere collateral damages. These wars were fought in dense urban environments, largely between uniformed state militaries and guerrillas in civilian clothing.

Attacking civilians, who act as shields to insurgents, supply them with information, sanctuary and groceries may be a necessary means for states victory in the war. This expedient means however amount to a conscious nonconformity to international law, but the greater the breach, the greater the chances of success for the counterinsurgents. To legitimize such breaches, the United States and Israel, among other great powers, have expanded the range of justifiable targets in asymmetric warfare to include civilians who directly or indirectly assist the insurgents. Such expansion has also been justified on the grounds that since insurgencies seek to undermine the government, the state may use any means at its disposal to subdue it; not doing so would strengthen the insurgents while threatening the government. It is therefore misleading in such situations to regard all civilians as innocent spectators. This perhaps led Michael Gross, while arguing for a revision of the current international laws of war, to contend in Moral Dilemmas of Modern War that the existing protection in international humanitarian law against civilian targets are constraining states from amply countering insurgents and therefore ineffective to tackle the intricacies of today's kind of wars. ${ }^{21}$ Similarly, Marc Herold's chapter in Inventing Collateral Damage raises doubt on the ability of modern technologies and legal statutes to protect civilians in asymmetric conflicts, arguing that the higher the degree of precision, the higher the casualty. ${ }^{22}$

Nevertheless, insurgents still capitalize on the assertion that the need to protect a government from topple is not enough justification for the violation of international law. A principal imperative of the international laws of armed conflict maintain that civilians must not be consciously targeted, except they openly take sides in the conflict. According to international humanitarian standard, military forces should not only direct their campaigns against combatants alone, but must as well wear uniforms and carry arms openly etc in order to distinguish themselves from non-combatants. When the status of the target is in doubt, military forces are expected to assume that they are civilians until otherwise proven. Further, the identification of a number of insurgents among a civilian population does not render such civilian population a justifiable target. These rules consequently serve as weapons for insurgents by constraining the counterinsurgents actions and giving the insurgents advantage to strike the counterinsurgents using civilians as shields. From this perspective, Van Creveld argued that:

By definition, a strong counterinsurgent who uses his strength to kill the members of a small, weak organization of insurgents - let alone the civilian population by which it is surrounded, and which may lend it support - will commit crimes in an unjust cause," while "a child who is in a serious fight with an adult is justified in using every and any means available - not because he or she is right, but because he or she has no choice. ${ }^{23}$

\footnotetext{
${ }^{20}$ Amnesty International, Stars on their Shoulders, Blood on their Hands: War Crimes Committed y the Nigerian Military, London: Amnesty International Ltd, June, 2015, p.4

${ }^{21}$ Michael Gross, Moral Dilemmas of Modern War: Torture, Assassination, and Blackmail in an Age of Asymmetric Conflict. Cited in Carpenter, Charli. "Fighting the Laws of War: Protecting Civilians in Asymmetric Conflict." Foreign Affairs Mar.-Apr. 2011: 146.

${ }^{22}$ Stephen Rockel and Rick Halpern (ed.s) Inventing Collateral Damage: Civilian Casualties, War, and Empire, cited in Carpenter, Charli. "Fighting the laws of war: protecting civilians in asymmetric conflict." Foreign Affairs, Mar.-Apr. 2011: 146.

23Van Creveld Martin, The Changing Face of War: Combat from the Marne to Iraq, 2008, New York: Ballantine, in Counter-insurgency Counter-insurgency Theorists - Martin Van Creveld, http://www.liquisearch.com/counter-insurgency/counterinsurgency theorists/martin van creveld, Accessed, $3^{\text {rd }}$ July, 2016
} 
As a panacea for this dilemma, some have recommended a "drain the water" or "drain the swamp" tactics, which involves the forced repositioning (drain) of the population (water) to expose the rebels or insurgents (fish), thereby depriving them of sanctuaries, supplies and Intelligence. This way, the government forces would be able to target the militia successfully, without putting the civilian population on harm's way. Nevertheless, the deficiency of this strategy is that local population may refuse to leave their villages and take shelter in a temporary camp until the war is over, especially where the duration of the war cannot be predicted. They often choose to be relocated by force; either by the insurgents or by government forces, if by the later, then another war crime would have been committed in the attempt to avoid one. Such was the dilemma of the United States in South Vietnam when they attempted to force the rural population into fenced camps called Strategic Hamlets.

The advantage that existing international humanitarian laws provide for insurgents, or more accurately, the weaponization of existing international humanitarian laws by insurgents, have led some scholars to question the capability of these laws to regulate today's kind of warfare, while others have out rightly called for its revision.

As Pfanner puts it:

Asymmetrical wars do not fit in with either Clausewitz's concept of war between basically equal parties or the traditional concept of international humanitarian law. It is debatable whether the challenges of asymmetrical war can be met with the current law of war. If wars between States are on the way out, perhaps the norms of international law that were devised for them are becoming obsolete as well. ${ }^{24}$

Arguing for a revision of the current laws of war, Osiel stated that:

Just as any other body of law, the Geneva Conventions have been regularly revised in light of novel challenges in warfare. In fact, major revisions have occurred about every twenty-five to thirty years. By that standard, the world is now due for another such reassessment. ${ }^{25}$

For Lauterpacht,

It is impossible to visualize the conduct of hostilities in which one side would be bound by the rules of warfare without benefiting from them and the other side would benefit from them without being bound by them. ${ }^{26}$

\section{CONCLUSION}

History has shown that many, if not most, of the weapons that have been fashioned by humankind were invented unconsciously, without any intention of using it for combat with other nations. While inventing the spear, early man possibly thought of it as means for hunting animals for the family meal. The inventors of the composite bow and those of the barbed wire must have considered it nothing other than a way of protecting their herds from predators, not for later use by Genghis khan to expand the Mongolian empire. Hiram Maxim, inventor of the machine gun and Alfred Nobel inventor of the dynamite, thought that their inventions would bring peace to the world by making war too horrible for nations to undertake. Nobel bragged that his invention would make war impossible with its very destructive power. On their own part, the Wright brothers who invented the aircraft probably did so because they envied the birds and wanted to fly like them, even faster. The idea of a nuclear energy was first conceived as a source of power, not for Albert Einstein and Manhattan to use against Hiroshima and Nagasaki. ${ }^{27}$

In like manner, the statesmen and diplomats that sat in the Hague and Geneva to invent the laws of war did so with the intention of regulating states behaviour in warfare. Perhaps, they never conceived of a kind of international warfare that would involve more that the Westphalian states against each other. However, with the emergence of non-state, rogue and vague actors in warfare, the laws have served to facilitate victory for these actors in combat against state actors; hence, this paper dub the existing laws of war as weapons of war in the hands of dissidents. This therefore brings to fore the need to revolutionize existing laws of war in accordance with

${ }^{24}$ Toni Pfanner, "Asymmetrical Warfare from the Perspective of Humanitarian Law and Humanitarian Action", International Review of the Red Cross, Volume 87 Number 857 March 2005, p.158

${ }_{25}$ Mark Osiel, The End of Reciprocity: Terror, Torture, and the Law of War, Cambridge: Cambridge University Press, 2009, p. 43.

${ }^{26}$ Lauterpacht Hersch, The Limits of Operation of the Laws of War, 1953, p. 212.

${ }^{27}$ see William Weir, 50 Weapons that Changed Warfare, London: Bounty Books, 2006, p.3 www.gjournals.org 
the revolution in warfare itself in order to meet the challenge of applying the existing laws to non-conventional warfare, and to curb the tendency for guerillas to "weaponize" these wars against the state. As Colby rightly observed, when savage or semi-savage peoples effect ruses, surprises, or massacres' against 'regular' troops, the uncivilized enemy must not be allowed to benefit from the international law of armed conflict.

\section{REFERENCES}

Amnesty International. (2015) Stars on their Shoulders, Blood on their Hands: War Crimes Committed y the Nigerian Military. London: Amnesty International Ltd.

Appadurai, Arjun. (2006). Fear of Small Numbers: An Essay on the Geography of Anger. Durham, NC: Duke University Press.

Arquilla, John. (2007). The End of War as We Knew it? Insurgency, Counterinsurgency and Lessons From the Forgotten History of Early Terror Networks. Third World Quarterly, 28, 369-86.

Arreguin-Toft, Ivan. (2001). 'How the Weak Win Wars: A Theory of Asymmetric Conflict. International Security, 26, 93-128.

Carpenter, Charli. (2011). Fighting the Laws of War: Protecting Civilians in Asymmetric Conflict. Foreign Affairs.

Cebrowski, Arthur K., and Garstka J. John . (1998). Network-Centric Warfare: Its Origin and Future. Proceedings, 124, 28-35.

Civilian Direct Participation in Hostilities and State Response. Master's Thesis in Public International Law, submitted to the Department of Law, Uppsala University.

Colby, Elbridge. (1927). How to Fight Savage Tribes. American Journal of International Law, 21, 279-88.

Counter-insurgency - Counter-insurgency Theorists - Martin Van Creveld. Retrieved $3^{\text {rd }}$ July, 2016 from http://www.liquisearch.com/counter-insurgency/counter insurgency theorists/martin van creveld.

Dinstein, Yoram. (2004). The Conduct of Hostilities Under the Law of International Armed Conflict. Cambridge, England: Cambridge University Press.

Excerpts from President Kennedy's Address at Graduation Exercises of the U.S. Military Academy, June 6, 1962. Source: The Pentagon Papers, Gravel Edition, Volume 2, p. 813.

Explanation of Vote by Ambassador Alejandro D. Wolff, Deputy Permanent Representative, on a UN General Assembly Resolution on the UN Fact-Finding Mission on the Gaza Conflict, in the General Assembly.(5 November 2009). US Mission to the United Nations, New York. Retrieved 16 April 2016 from: http://usun.state.gov/briefing/statements/2009/131448.htm.

France in Algeria, Israel in Lebanon, and the United States in Vietnam. Cambridge: Cambridge University Press.

$\mathrm{GCl}$ - Geneva Convention for the Amelioration of the Condition of the Wounded and Sick in Armed Forces in the Field, of 12 August 1949.

GCII-Geneva Convention for the Amelioration of the Condition of Wounded, Sick and Shipwrecked Members of Armed Forces at Sea, of 12 August 1949.

GCIII- Geneva Convention relative to the Treatment of Prisoners of War, of 12 August 1949.

GCIV Geneva Convention relative to the Protection of Civilian Persons in Time of War, of 12 August 1949.

Gross, Michael. (2009). Moral Dilemmas of Modern War: Torture, Assassination, and Blackmail in an Age of Asymmetric Conflict. Cambridge: Cambridge University Press.

Henkaerts, Jean-Marie and Doswald-Beck, Louise. (2005). Customary International Humanitarian Law. Cambridge, England: Cambridge University Press.

Kitson, Frank. (1971). Low Intensity Operations: Subversion, Insurgency, Peace-Keeping. London: Faber and Faber.

Kolb, Robert and Hyde, Richard. (2008). An Introduction to the International Law of Armed Conflicts. Cumnor, Oxford: Hart Publishers.

Lind, William S. (2004). 'Understanding Fourth Generation War. Military Review 84(September/ October):12-16.

Lind, William S., Keith Nightengale, John F. Schmitt, Joseph W. Sutton and Gary I. Wilson. (1989). The Changing Face of War: Into the Fourth Generation. Marine Corps Gazette, 73(October), 22-26.

Lindström, Frida. (2012). Asymmetric Warfare and Challenges for International Humanitarian Law: Civilian Direct Participation in Hostilities and State Response. Master's Thesis in Public International Law, submitted to the Department of Law, Uppsala University.

Mack, Andrew. (1975). Why Big Nations Lose Small Wars: The Politics of Asymmetric Conflict. World Politics, 27, 175-200.

Mattis, James N., and Frank Hoffman. (2005). Future Warfare: The Rise of Hybrid Wars. Proceedings, 131, 1819.

Merom, Gil. (2003). How Democracies Lose Small Wars: State, Society, and the Failures of France in Algeria, Israel in Lebanon, and the United States in Vietnam. Cambridge: Cambridge University Press.

O'Neill, B. (2005). Insurgency and Terrorism: From Revolution to Apocalypse (2 ${ }^{\text {nd }}$ ed.). Washington D. C.: Potomac Books, Inc. 
Osiel, Mark. (2009). The End of Reciprocity: Terror, Torture, and the Law of War. Cambridge: Cambridge University Press.

Paul, T. V. (1994). Asymmetric Conflicts: War Initiation By Weaker Powers. Cambridge: Cambridge University Press.

Protocol Additional to the Geneva Conventions of 12 August 1949, and Relating to the Protection of Victims of International Armed Conflicts (Protocol I), 8 June 1977.

Rockel, Stephen and Halpern, Rick (ed.s). (2009). Inventing Collateral Damage: Civilian Casualties, War, and Empire. Toronto: Between the Lines.

Strategy and Tactics of Guerrilla Warfare (n.d.). Retrieved May 31, 2016 from https://en.wikipedia.org/wiki/Strategy_and_tactics_of_guerrilla_warfare.

Taber, R. (2002) War of the Flea: The Classic Study of Guerilla Warfare, Dulles.: Potomac Books Inc.

Thomas Hammes (n.d.). Countering Evolved Insurgents Network. Retrieved 24 $4^{\text {th }}$ May, 2016 from http://www.au.af. mil/au/ awc/awcgate/milreview/hammes.pdf.

Toni Pfanner. (2005). Asymmetrical Warfare from the Perspective of Humanitarian Law and Humanitarian Action. International Review of the Red Cross, 87:857.

U.S. Government Counterinsurgency Guide. (2009). Retrieved from Bureau of Political-Military Affairs, Department of State. Website: www.state.gov/documents/organization/119629/pdf.

U.S. Marine Corps. (1940). Small Wars Manual. NAVMC 2890.

Van Creveld Martin. (2008). The Changing Face of War: Combat from the Marne to Iraq. New York: Ballantine.

Van Creveld, Martin. (1991). The Transformation of War. New York: Macmillan.

Weir, William. (2006). 50 Weapons that Changed Warfare, London: Bounty Books.

Winter, Y. (2011). The Asymmetric War Discourse and its Moral Economies: A Critique. International Theory, $3: 3,488-514$.

Cite this Article: Emah Saviour-Peter and Ekah J.A. (2017). Small Wars and the War Crime Dilemma: The "Weaponization" of the Laws of War in Non-Conventional Warfare. Greener Journal of Social Sciences, 7(4): 045-053, http://doi.org/10.15580/GJSS.2017.4.101017146 